\title{
The biocompatibility of Achyrocline satureioides plant extract over human gingival
}

\section{fibroblasts}

\section{A biocompatibilidade do extrato da planta Achyrocline satureioides sobre fibroblastos gengivais}

\section{humanos}

\section{La biocompatibilidad del extracto de la planta Achyrocline satureioides en fibroblastos gingivales}

\section{humanos}

Elis Cecília Castro Ferreira ORCID: https://orcid.org/0000-0001-8926-0017 São Paulo State University, Brazil E-mail: Elisccf31@gmail.com

Taciano Moreira Gonçalves ORCID: https://orcid.org/0000-0002-7264-1136 São Paulo State University, Brazil

E-mail: taciano.goncalves@unesp.br

Thaís Cristine Pereira

ORCID: https://orcid.org/0000-0002-7206-3348 São Paulo State University, Brazil E-mail: thatha.this@hotmail.com

Amjad Abu Hasna

ORCID: https://orcid.org/0000-0002-1112-985X São Paulo State University, Brazil E-mail: d.d.s.amjad@gmail.com

Felipe Eduardo de Oliveira ORCID: https://orcid.org/0000-0003-3026-646X São Paulo State University, Brazil

E-mail: felipe.eoliveira@ymail.com

Adeline Lacerda Jorjão

ORCID: https://orcid.org/0000-0003-4409-9738 São Paulo State University, Brazil E-mail: adelinejorjao@gmail.com

Samira Esteves Afonso Camargo ORCID: https://orcid.org/0000-0002-2527-0651 University of Florida, USA E-mail: scamargo@dental.ufl.edu

Luciane Dias de Oliveira ORCID: https://orcid.org/0000-0002-5465-9551 São Paulo State University, Brazil E-mail: Luciane.oliveira@unesp.br Marianne Spalding

ORCID: https://orcid.org/0000-0003-3667-2434 São Paulo State University, Brazil E-mail: m.spalding@unesp.br

\begin{abstract}
Objective: Achyrocline satureioides "A.satureioides" is a subshrub, widely distributed in South America because of its medicinal properties. Although it is widely used in folk medicine, there is still no approval for its therapeutic use, and its biocompatibility is little explored. This study aimed to evaluate its cytotoxicity and genotoxicity over human gingival fibroblasts (FMM-1). Methodology: Ten different concentration of the glycolic extract of A.satureioides were tested for $5 \mathrm{~min}$ and $24 \mathrm{~h}$ of contact with the cells to evaluate its cytotoxicity using the MTT colorimetric assay and to evaluate its genotoxicity using the micronucleus assay. Data were analyzed with one-way ANOVA and Tukey test with a significance level $(\alpha=0.05)$. Results: All tested concentrations of the extract presented cell viability more than $70 \%$ and has no significant difference of the control group after $5 \mathrm{~min}$ and $24 \mathrm{~h}$. However, for $5 \mathrm{~min}$ the 100 $\mathrm{mg} / \mathrm{mL}$ was cytotoxic and for $24 \mathrm{~h}$ the $1.56 \mathrm{mg} / \mathrm{mL}$ stimulated cell proliferation. For genotoxicity analysis, only the concentration $6.25 \mathrm{mg} / \mathrm{mL}$ showed results similar to the control of cell culture in the micronucleus count after $5 \mathrm{~min}$ and 24h. Conclusions: The glycolic extract of A.satureioides doesn't have cytotoxic and genotoxic effects in concentrations up to $6.25 \mathrm{mg} / \mathrm{mL}$, but in high concentrations it is considered genotoxic.
\end{abstract}


Keywords: Fibroblasts; Plant extracts; Phytotherapy.

\begin{abstract}
Resumo
Objetivo: Achyrocline satureioides "A.satureioides" é um subarbusto amplamente distribuído na América do Sul por suas propriedades medicinais. Embora seja amplamente utilizado na medicina popular, ainda não há aprovação para seu uso terapêutico e a sua biocompatibilidade é pouco explorada. Este estudo teve como objetivo avaliar sua citotoxicidade e genotoxicidade sobre fibroblastos gengivais humanos (FMM-1). Metodologia: Dez diferentes concentrações do extrato glicólico de A. satureioides foram testadas por $5 \mathrm{~min}$ e $24 \mathrm{~h}$ de contato com as células para avaliar sua citotoxicidade pelo ensaio colorimétrico MTT e para avaliar sua genotoxicidade pelo ensaio do micronúcleo. Os dados foram analisados com ANOVA one-way e teste de Tukey com nível de significância $(\alpha=$ 0,05). Resultados: Todas as concentrações testadas do extrato apresentaram viabilidade celular superior a $70 \%$ e não houve diferença significativa do grupo controle após $5 \mathrm{~min}$ e $24 \mathrm{~h}$. Porém, por $5 \mathrm{~min}$ a $100 \mathrm{mg} / \mathrm{mL}$ foi citotóxica e por $24 \mathrm{~h}$ o $1,56 \mathrm{mg} / \mathrm{mL}$ estimulou a proliferação celular. Para a análise de genotoxicidade, apenas a concentração $6,25 \mathrm{mg}$ $/ \mathrm{mL}$ apresentou resultados semelhantes ao controle de cultura de células na contagem de micronúcleos após 5min e 24h. Conclusão: $\mathrm{O}$ extrato glicólico de A. satureioides não apresenta efeitos citotóxicos e genotóxicos em concentrações de até $6,25 \mathrm{mg} / \mathrm{mL}$ mas em altas concentrações é considerado genotóxico.
\end{abstract}

Palavras-chave: Fibroblastos; Extratos vegetais; Fitoterapia.

\title{
Resumen
}

Objetivo: Achyrocline satureioides "A.satureioides" es un subarbusto ampliamente distribuido en América del Sur por sus propiedades medicinales. Aunque es muy utilizado en la medicina popular, todavía no hay aprobación para su uso terapéutico y su biocompatibilidad está poco explorada. Este estudio tuvo como objetivo evaluar su citotoxicidad y genotoxicidad en fibroblastos gingivales humanos (FMM-1). Metodología: Se probaron diez concentraciones diferentes del extracto glicólico de A. satureioides durante $5 \mathrm{~min}$ y $24 \mathrm{~h}$ de contacto con las células para evaluar su citotoxicidad mediante el ensayo colorimétrico MTT y su genotoxicidad mediante el ensayo de micronúcleos. Los datos fueron analizados con ANOVA de una vía y prueba de Tukey con nivel de significancia $(\alpha=0.05)$. Resultados: Todas las concentraciones probadas del extracto mostraron una viabilidad celular superior al $70 \%$ y no hubo diferencias significativas en el grupo de control después de $5 \mathrm{~min}$ y $24 \mathrm{~h}$. Sin embargo, durante 5 minutos a $100 \mathrm{mg} /$ $\mathrm{ml}$ fue citotóxico y durante 24 horas, $1,56 \mathrm{mg} / \mathrm{ml}$ estimuló la proliferación celular. Para el análisis de genotoxicidad, solo la concentración $6.25 \mathrm{mg} / \mathrm{mL}$ presentó resultados similares al control de cultivo celular en el recuento de micronúcleos a los $5 \mathrm{~min}$ y $24 \mathrm{~h}$. Conclusión: El extracto glicólico de A. satureioides no tiene efectos citotóxicos y genotóxicos en concentraciones de hasta $6.25 \mathrm{mg} / \mathrm{mL}$ pero en concentraciones altas se considera genotóxico.

Palabras clave: Fibroblastos; Extractos vegetales; Fitoterapia.

\section{Introduction}

Phytotherapy was used in dentistry and more specifically in endodontics since the last century (Groppo et al., 2008) due to its antimicrobial, anti-inflammatory and antifungal actions and because it is considered biocompatible (Guandalini Cunha et al., 2020; De La Chapa, Singha, Lee, \& Gonzales, 2018; Marcia C Valera et al., 2016; Viegas et al., 2020) in addition to other techniques like photodynamic therapy and passive ultrasonic irrigation (Abu Hasna, Ferrari, \& Talge Carvalho, 2019; Abu Hasna, Khoury, et al., 2020; Abu Hasna, Pereira Da Silva, et al., 2020). This use was encouraged by the World Health Organization (WHO); however, the agency establishes specific safety requirements including traditional use certificate and toxicity analyzes of the extracts (Organization, 2019).

Achyrocline satureioides "A. satureiroides" is a plant belonging to the Asteraceae family, popularly named "macela" or "marcela", it is a subshrub, widely distributed in South America and very common in Brazil (Ferraro et al., 2008; Lorenzo et al., 2000). Different extracts and purified fractions (polysaccharides and flavonoids) from A. satureiroides inflorescences, leaves and stems have been studied and their therapeutic use is related to their antibacterial, antiviral, analgesic, Immunomodulatory, hepatoprotective, muscle relaxant, anti-herpetic and antioxidant effects (Calvo, Cariddi, Grosso, Demo, \& Maldonado, 2006; Desmarchelier, Coussio, \& Ciccia, 1998; Hnatyszyn et al., 2004; Joray, del Rollán, Ruiz, Palacios, \& Carpinella, 2011; Kadarian et al., 2002; Santos, Ripoll, Nardi, \& Bassani, 1999; Zanon, Ceriatti, Rovera, Sabini, \& Ramos, 1999). Recently, it was suggested as alternative approach for management of viral respiratory infections, including the Severe Acute Respiratory Syndrome Coronavirus 2 (SARS-COV2) (Siqueira, Simões, \& Bassani, 2020). 
Even A. satureioides extracts are widely used in folk medicine (Polydoro et al., 2004). The literature reported divergent results about its biocompatibility by few in vitro and in vivo studies (Calvo et al., 2006; Polydoro et al., 2004; Rivera, Gervaz, Sere, \& Dajas, 2004; M C Sabini et al., 2013). To the best of our knowledge there is not studies evaluated the biocompatibility of $A$. satureioides extracts over the oral cells.

Therefore, this study aimed to evaluate the cytotoxic and genotoxic effects of $A$. satureoides extracts over human gingival fibroblasts (FMM-1) in periods of $5 \mathrm{~min}$ and $24 \mathrm{~h}$ of contact by MTT and micronucleus assays respectively, to assist in the future development of dental materials like intracanal medications, endodontic irrigants, mouthwashes and toothpastes.

\section{Methodology}

\subsection{Extract and cells lineage}

The glycolic extract of $A$. satureiroides was used at a concentration of $200 \mathrm{mg} / \mathrm{mL}$ (20\%) diluted in propyleneglycol (Mapric - São Paulo, SP).

Human gingival fibroblasts (FMM-1) (Faculty of Dentistry, University of São Paulo, São Paulo, Brazil) were cultured routinely in Dulbecco's modified Eagle's medium "DMEM" (DMEM - LGC Biotecnologia, Cotia, Brazil) and supplemented with $10 \%$ fetal bovine serum (SFB - Gibco, USA) at $37{ }^{\circ} \mathrm{C}$ in an atmosphere of $5 \% \mathrm{CO}_{2}$. The Trypan blue exclusion test $(0.5 \%$, Sigma-Aldrich, St. Louis, MO, USA) was performed to quantify viable cells.

\subsection{Cytotoxicity analysis by MTT assay}

In 96-well plates, $200 \mu \mathrm{L}$ of DMEM $+10 \%$ SFB medium containing $2 \times 10^{4}$ viable cells were added. These plates were incubated at $37{ }^{\circ} \mathrm{C}$ with $5 \% \mathrm{CO} 2$ for $24 \mathrm{~h}$. Then, the cells were exposed to $200 \mu \mathrm{L} /$ well of 10 different concentrations of A. satureioides extract $(0.195,0.390,0.781,1.562,3.125,6.25,12.5,25,50$ and $100 \mathrm{mg} / \mathrm{mL}), \mathrm{n}=12$ for each group, and incubated for a period of $5 \mathrm{~min}$ and 24 at $37^{\circ} \mathrm{C}$ with $5 \% \mathrm{CO} 2$. Culture medium cells were used as a positive control group without any extract.

The plates were washed with phosphate buffered saline (PBS - Cultilab, Campinas, SP, Brazil) and the MTT solution $(100 \mu \mathrm{L} / w e l l)$ was added to the 96-well plate. The plates were incubated at $37{ }^{\circ} \mathrm{C}$ with $5 \% \mathrm{CO} 2$ for $1 \mathrm{~h}$. Later, the MTT solution was discarded and $100 \mu \mathrm{L}$ / well of dimethyl sulfoxide (DMSO - Sigma) was added and the plated incubated again fot 10 min. Lastly, the plates were shaken for $10 \mathrm{~min}$ and read by a multi-well spectrophotometer (Bio-Tek, Winooski, Vermont, USA) at $570 \mathrm{~nm}$. The obtained optical densities (OD) were converted into a percentage of cell viability using the following formula: \% Viability $=($ OD of treated group x 100) / average OD of the control group (Memari Trava et al., 2020).

\subsection{Genotoxicity analysis by micronucleus assay}

In 24-well plates, FMM-1 were grown in DMEM (LGC Biotechnology) medium supplemented with 10\% fetal bovine serum (SFB) (Invitrogen) where $2 \times 10^{4}$ cells / well were plated and incubated at $37{ }^{\circ} \mathrm{C}$ with $5 \% \mathrm{CO} 2 \mathrm{for} 24 \mathrm{~h}$. Then, the cells were exposed to A. satureioides extracts diluted in DMEM + 10\% SFB and to ethyl methane sulfanate (EMS); 5 mM as a positive control group for $24 \mathrm{~h}$.

Later, the cells were fixed with $4 \%$ formaldehyde. Then, $500 \mu \mathrm{L}$ of PBS and 1 drop of Fluoroshield solution with DAPI (Sigma-Aldrich) were added to the wells, which were photographed with a digital camera (Sony F828 digital, CyberShot, 8.0 megapixels) coupled with an inverted light microscope. At least 10 photos per well were taken and the number of micronuclei was determined to be 2,000 cells / well. DNA structures contained in the cytoplasm separated from the main nucleus were identified as micronuclei, with an area less than 1/3 of the main nucleus area. Cells in mitosis and that exhibited 
nuclear fragmentation by apoptosis were not considered in the count (Oliveira et al., 2017; Sousa et al., 2020).

\subsection{Statistical analysis}

The data were statistically analyzed using the one-way ANOVA and Tukey tests, with a significance level of 5\% by GraphPad Prism 6 (La Jolla, CA, USA).

\section{Results}

\subsection{MTT assay}

In the 5 min contact period, all the tested concentration of the extract presented cell viability more than $70 \%$ and has no significant difference of the control group. Conversely, the $100 \mathrm{mg} / \mathrm{mL}$ of the extract presented $65.9 \%$ of cell viability and had significant difference of the control group $(\mathrm{p}<0.05)$ (Figure. 1).

Figure 1 - Percentage $(\%)$ of the viability of FMM-1 in contact with different concentrations of A. satureioides extract for 5 $\min$.

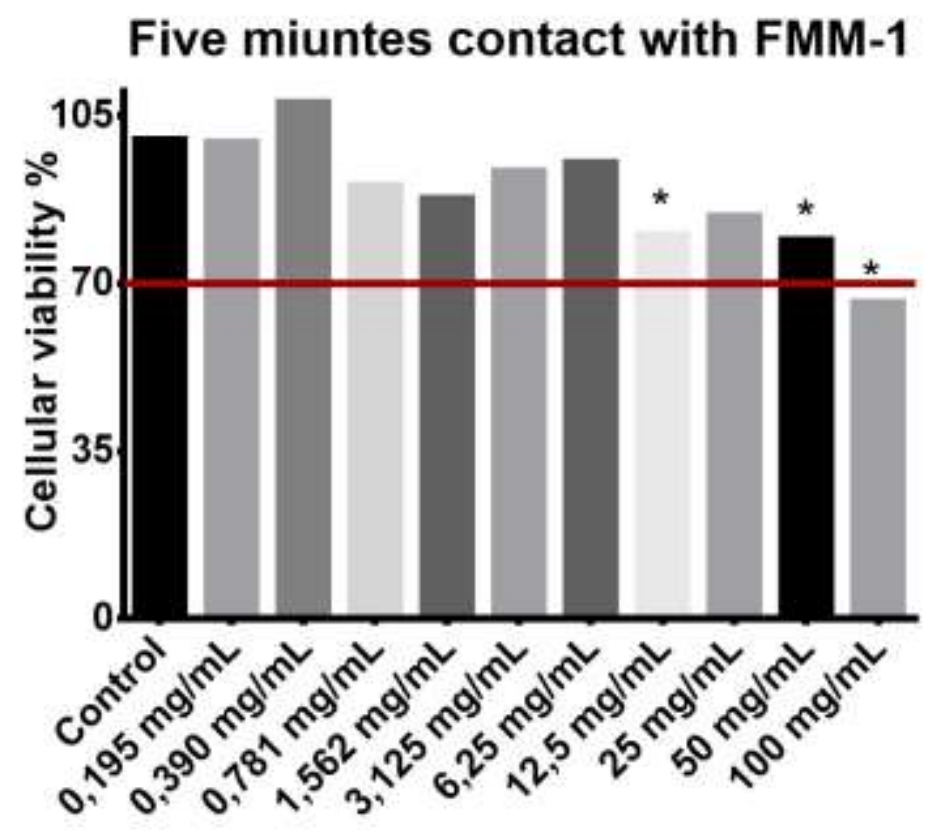

Source: Authors.

In the $24 \mathrm{~h}$ contact period, all the tested concentrations showed cell viability greater than $70 \%$ and has no significant difference of the control group except the concentration of $1.56 \mathrm{mg} / \mathrm{mL}$ that significantly stimulated cell proliferation compared to the control group ( $\mathrm{p}<0.05)$ (Figure. 2). 
Figure 2 - Percentage (\%) of the viability of FMM-1 in contact with different concentrations of A. satureioides extract for 24 hours.

\section{4 hours contact with FMM-1}

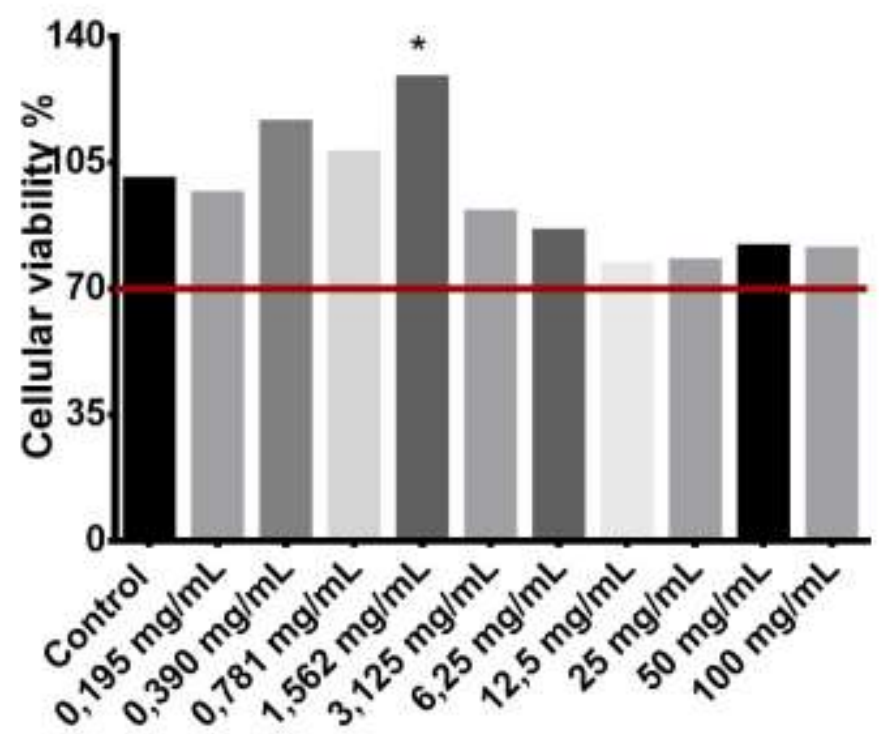

Source: Authors.

\subsection{Genotoxicity assay}

In the 5 minutes contact period, the micronucleus count increased according to the extract concentration, with the highest concentration analyzed $(100 \mathrm{mg} / \mathrm{mL})$ averaging 13.5 micronuclei. Only the concentration of $6.25 \mathrm{mg} / \mathrm{mL}$ of the extract showed similar results to the control (Figure. 3). As well, in the $24 \mathrm{~h}$ contact period, the concentration $6.25 \mathrm{mg} / \mathrm{mL}$ also showed results similar to the control of cell culture in the micronucleus count (Figure. 4).

Figure 3 - Counting of micronuclei after contact of FMM-1 with different concentrations of A. satureioides extract for 5 min.

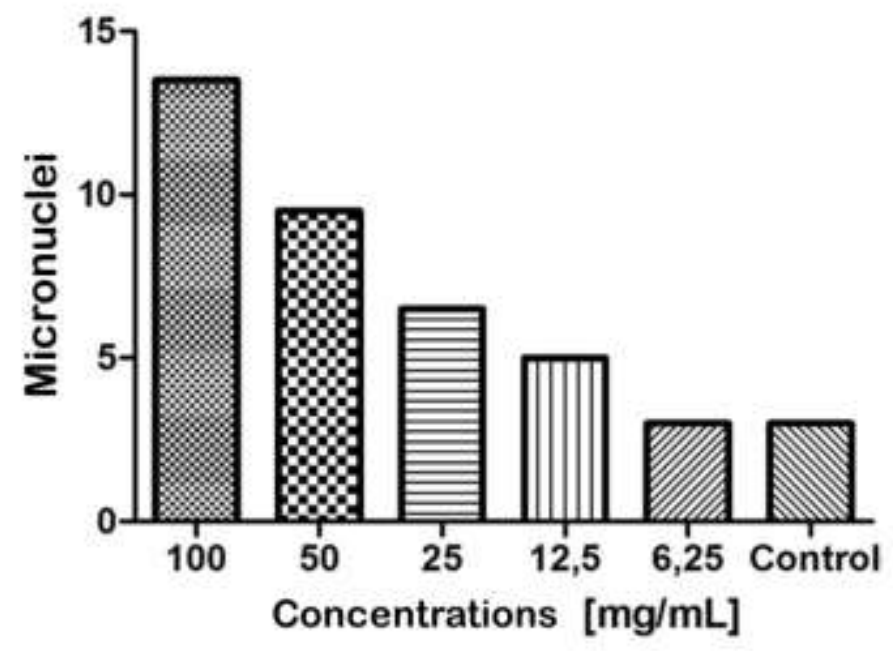

Source: Authors. 
Figure 4 - Counting of micronuclei after contact of FMM-1 with the concentration of $6.25 \mathrm{mg} / \mathrm{mL}$ of A. satureioides extract for 24 hours.

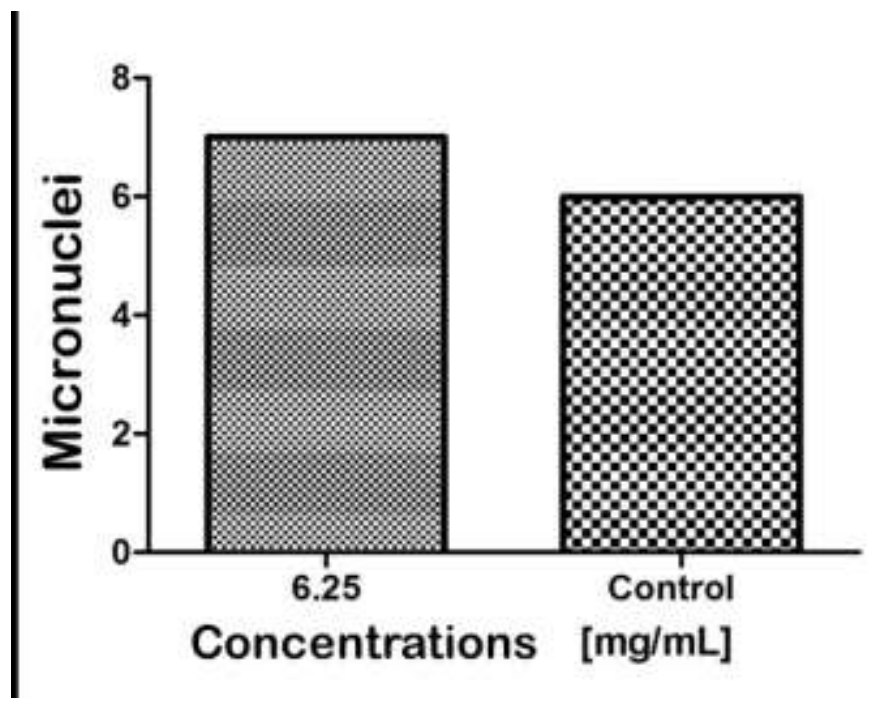

Source: Authors.

\section{Discussion}

Diverse plant extracts were used in dentistry principally as endodontic irrigant or intracanal medication (Horiba, Maekawa, Ito, Matsumoto, \& Nakamura, 1991; Maekawa et al., 2015; Qunqiang \& Farnham, 1989; Marcia C Valera et al., 2016) or even associated with other intracanal medication (Marcia Carneiro Valera et al., 2015) and this may be related to the fact of the increased resistance of micro-organisms against antibiotics overtime (Jungermann et al., 2011).

The aim of this study was to introduce the A. satureioides extract to be used like others (Ghonmode et al., 2013) as an effective substance over the endodontic and oral pathogens. For this, the cytotoxicity of the extract was evaluated over the human gingival fibroblasts (FMM-1). In this study, it was founded that the different concentrations of the extract were biocompatible and had no significant difference of the control group (without extract) when applied for 5 minutes or 24 hours, except of the $100 \mathrm{mg} / \mathrm{mL}$ concentration when applied for 5 minutes. Even more, the concentration of $1.56 \mathrm{mg} / \mathrm{mL}$ that significantly stimulated cell proliferation compared to the control group when applied for 24 hours.

To the best of our knowledge, there is no studies in the literature evaluated the effect of A. satureioides extract over oral cells. The study of Guss et al. (2017) evaluated this effect over mice fibroblasts and macrophage cell lines; however, it did not define the fibroblast cell line exactly, in this study, it was concluded that the extract show no toxicity to fibroblasts agreeing with the results of the present study (Guss et al., 2017). Even more, the extract has no toxic effect over the human peripheral blood mononuclear cells (M C Sabini et al., 2013). It was also verified that only high concentrations of cold extract of A. satureioides induced cytotoxicity, corroborating the current study, when the concentration of $100 \mathrm{mg} / \mathrm{mL}$ of glycolic extract of A. satureioides promoted viability of FMM-1 below 70\% (65.9\%), demonstrating that higher concentrations of the extract are cytotoxic (María Carola Sabini et al., 2012). Low toxicity was also identified by Salgueiro et al. (2016), the authors used extracts obtained by water infusion and tested its cytotoxic over human lymphocytes and it presented low toxicity (Salgueiro et al., 2016).

In this study as well, the genotoxicity of the extract was evaluated, and it was founded that, the major the extract concentration, the major the genotoxicity, being its dose-dependent genotoxic potential. Only the concentration of $6.25 \mathrm{mg} /$ $\mathrm{mL}$ of the extract showed similar results to the control group in both $5 \mathrm{~min}$ and $24 \mathrm{~h}$ contact period. 
In the literature, similar results were obtained, Sabini et al. (2013) found that the cold aqueous A. satureioides extract did not show genotoxicity in vitro against Vero cells in the concentration of 10 to $50 \mu \mathrm{g} / \mathrm{mL}$, but in high concentrations it was genotoxic by the micronucleus assay (M C Sabini et al., 2013) and in a previous study, it was concluded the absence of genotoxicity of cold aqueous extract of $A$. satureioides by Allium test. These findings show the existence of a limit between safe and toxic concentrations that need to be further studied in order to guarantee safety for clinical use.

Beside the extract concentration, another point to be emphasized is the extract temperature, it seems that the hot aqueous extract of $A$. satureioides is more cytotoxic and genotoxic over cells than cold one and this may be related to high concentrations of flavonoids including luteolin, quercetin, and 3-O-methylquercetin (Cariddi et al., 2015). In this study, the extract was used at room temperature.

Then, the results obtained in the present study suggest the use of the A. satureioides at low concentration (below 6,25 $\mathrm{mg} / \mathrm{mL}$ ) as it presents lower cytotoxicity and genotoxicity and preferably to use the cold or room-temperature extract when used as a component of dental products like mouthwashes, toothpastes, or as endodontic irrigant and intracanal medication bringing benefits to the population.

\section{Conclusion}

It may be concluded that:

- The glycolic extract of A. satureioides $(\leq 50 \mathrm{mg} / \mathrm{mL})$ was not cytotoxic to gingival fibroblasts, in the periods of 5 min and $24 \mathrm{~h}$ of contact.

- The concentration of $6.25 \mathrm{mg} / \mathrm{mL}$ of the glycolic extract of A. satureioides did not induce an increase in micronucleus production in the two periods tested, with no genotoxicity.

- The concentration of $6.25 \mathrm{mg} / \mathrm{mL}$ of the glycolic extract of A. satureioides is indicated to be used as component of mouthwashes, toothpastes, or as endodontic irrigant and intracanal medication bringing benefits to the population.

\section{Acknowledgments}

The authors deny any conflict of interest. Source of Funding: This work was supported by PIBIC Ensino Medio (N 2757).

\section{References}

Abu Hasna, A., Ferrari, C. H., \& Talge Carvalho, C. A. (2019). Endodontic treatment of a large periapical cyst with the aid of antimicrobial photodynamic therapy - Case report. Brazilian dental science, 22(4), 561-568. doi:10.14295/bds. 2019. v.22i4.1745

Abu Hasna, A., Khoury, R. D., Toia, C. C., Gonçalves, G. B., de Andrade, F. B., Claudio António Talge Carvalho, ... Valera. (2020). In vitro Evaluation of the Antimicrobial Effect of $\mathrm{N}$-acetylcysteine and Photodynamic Therapy on Root Canals Infected with Enterococcus faecalis. Iranian Endodontic Journal.

Abu Hasna, A., Pereira Da Silva, L., Pelegrini, F. C., Ferreira, C. L. R., de Oliveira, L. D., \& Carvalho, C. A. T. (2020). Effect of sodium hypochlorite solution and gel with/without passive ultrasonic irrigation on Enterococcus faecalis, Escherichia coli and their endotoxins. F1000Research, 9, 642. doi:10.12688/f1000research.24721.1

Calvo, D., Cariddi, L. N., Grosso, M., Demo, M. S., \& Maldonado, A. M. (2006). Achyrocline satureioides (LAM.) DC (Marcela): antimicrobial activity on Staphylococcus spp. and immunomodulating effects on human lymphocytes. Revista latinoamericana de microbiologia, 48(3-4), $247-255$.

Cariddi, L. N., Sabini, M. C., Escobar, F. M., Bacchetti, R., Montironi, I., Merckis, C., ... Sabini, L. I. (2015). In Vitro and In Vivo Cytogenotoxic Effects of Hot Aqueous Extract of Achyrocline satureioides (Lam.) DC. BioMed research international, 2015, 270973. doi:10.1155/2015/270973

De La Chapa, J. J., Singha, P. K., Lee, D. R., \& Gonzales, C. B. (2018). Thymol inhibits oral squamous cell carcinoma growth via mitochondria-mediated apoptosis. Journal of Oral Pathology \& Medicine, 47(7), 674-682. doi:10.1111/jop.12735 
Desmarchelier, C., Coussio, J., \& Ciccia, G. (1998). Antioxidant and free radical scavenging effects in extracts of the medicinal herb Achyrocline satureioides (Lam.) DC. ("marcela"). Brazilian Journal of Medical and Biological Research, 31(9), 1163-1170.

Ferraro, G., Anesini, C., Ouviña, A., Retta, D., Filip, R., Gattuso, M., ... Bandoni, A. (2008). Total Phenolic Content and Antioxidant Activity of Extracts of Achyrocline satureioides Flowers from Different Zones in Argentina. undefined.

Ghonmode, W. N., Balsaraf, O. D., Tambe, V. H., Saujanya, K. P., Patil, A. K., \& Kakde, D. D. (2013). Comparison of the antibacterial efficiency of neem leaf extracts, grape seed extracts and 3\% sodium hypochlorite against E. feacalis - An in vitro study. Journal of international oral health: JIOH, 5(6), 61-66.

Groppo, F. C., Bergamaschi, C. de C., Cogo, K., Franz-Montan, M., Motta, R. H. L., \& de Andrade, E. D. (2008). Use of phytotherapy in dentistry. Phytotherapy Research, 22(8), 993-998. doi:10.1002/ptr.2471

Guandalini Cunha, B., Duque, C., Sampaio Caiaffa, K., Massunari, L., Araguê Catanoze, I., Dos Santos, D. M., ... Guiotti, A. M. (2020). Cytotoxicity and antimicrobial effects of citronella oil (Cymbopogon nardus) and commercial mouthwashes on S. aureus and C. albicans biofilms in prosthetic materials. Archives of Oral Biology, 109, 104577. doi:10.1016/j.archoralbio.2019.104577

Guss, K. L., Pavanni, S., Prati, B., Dazzi, L., de Oliveira, J. P., Nogueira, B. V., ... Scherer, R. (2017). Ultrasound-assisted extraction of Achyrocline satureioides prevents contrast-induced nephropathy in mice. Ultrasonics Sonochemistry, 37, 368-374. doi:10.1016/j. ultsonch. 2017.01.035

Hnatyszyn, O., Moscatelli, V., Rondina, R., Costa, M., Arranz, C., Balaszczuk, A., ... Ferraro, G. (2004). Flavonoids from Achyrocline satureioides with relaxant effects on the smooth muscle of Guinea pig corpus cavernosum. Phytomedicine: International Journal of Phytotherapy and Phytopharmacology, 11(4), 366-369. doi:10.1078/0944711041495182

Horiba, N., Maekawa, Y., Ito, M., Matsumoto, T., \& Nakamura, H. (1991). A pilot study of Japanese green tea as a medicament: antibacterial and bactericidal effects. Journal of Endodontics, 17(3), 122-124. doi:10.1016/S0099-2399(06)81743-7

Joray, M. B., del Rollán, M. R., Ruiz, G. M., Palacios, S. M., \& Carpinella, M. C. (2011). Antibacterial activity of extracts from plants of central Argentina-isolation of an active principle from Achyrocline satureioides. Planta Medica, 77(1), 95-100. doi:10.1055/s-0030-1250133

Jungermann, G. B., Burns, K., Nandakumar, R., Tolba, M., Venezia, R. A., \& Fouad, A. F. (2011). Antibiotic resistance in primary and persistent endodontic infections. Journal of Endodontics, 37(10), 1337-1344. doi: 10.1016/j. joen. 2011.06.028

Kadarian, C., Broussalis, A. M., Miño, J., Lopez, P., Gorzalczany, S., Ferraro, G., \& Acevedo, C. (2002). Hepatoprotective activity of Achyrocline satureioides(Lam) D. C. Pharmacological Research, 45(1), 57-61. doi:10.1006/phrs.2001.0904

Lorenzo, D., Atti-Serafini, L., Santos, A. C., Frizzo, C. D., Paroul, N., Paz, D., ... Moyna, P. (2000). Achyrocline satureioides essential oils from southern Brazil and Uruguay. Planta Medica, 66(5), 476-477. doi:10.1055/s-2000-8590

Maekawa, L. E., Rossoni, R. D., Barbosa, J. O., Jorge, A. O. C., Junqueira, J. C., \& Valera, M. C. (2015). Different extracts of Zingiber officinale decrease Enterococcus faecalis infection in Galleria mellonella. Brazilian dental journal, 26(2), 105-109. doi:10.1590/0103-6440201300199

Memari Trava, G., Almeida Santos, J., Paula Ramos, L., Rosário Estevam dos Santos, P. B., Abu Hasna, A., Yui, K. C., ... Spalding, M. (2020). The effect of halogen bulb and light-emitting diode light curing units on temperature increase and fibroblast viability. F1000Research, 9, 1369. doi:10.12688/f1000research.25456.1

Oliveira, J. R. de, de Jesus Viegas, D., Martins, A. P. R., Carvalho, C. A. T., Soares, C. P., Camargo, S. E. A., ... de Oliveira, L. D. (2017). Thymus vulgaris L. extract has antimicrobial and anti-inflammatory effects in the absence of cytotoxicity and genotoxicity. Archives of Oral Biology, 82, 271-279. doi: 10.1016/j. archoralbio. 2017.06.031

Organization, W. H. (2019). Who Global Report On Traditional And Complementary Medicine 2019 (1st ed., p. 226). [Geneva, Switzerland]: World Health Organization.

Polydoro, M., de Souza, K. C. B., Andrades, M. E., Da Silva, E. G., Bonatto, F., Heydrich, J., ... Moreira, J. C. F. (2004). Antioxidant, a pro-oxidant and cytotoxic effects of Achyrocline satureioides extracts. Life Sciences, 74(23), 2815-2826. doi:10.1016/j.lfs.2003.09.073

Qunqiang, L., \& Farnham, S. (1989). Clinical experience with Chinese herbs in endodontic therapy. General dentistry, 37(3), 234.

Rivera, F., Gervaz, E., Sere, C., \& Dajas, F. (2004). Toxicological studies of the aqueous extract from Achyrocline satureioides (Lam.) DC (Marcela). Journal of Ethnopharmacology, 95(2-3), 359-362. doi:10.1016/j.jep.2004.08.013

Sabini, M C, Cariddi, L. N., Escobar, F. M., Mañas, F., Comini, L., Reinoso, E., ... Sabini, L. I. (2013). Evaluation of the cytotoxicity, genotoxicity and apoptotic induction of an aqueous extract of Achyrocline satureioides (Lam.) DC. Food and Chemical Toxicology, 60, 463-470. doi:10.1016/j.fct.2013.08.005

Sabini, María Carola, Escobar, F. M., Tonn, C. E., Zanon, S. M., Contigiani, M. S., \& Sabini, L. I. (2012). Evaluation of antiviral activity of aqueous extracts from Achyrocline satureioides against Western equine encephalitis virus. Natural Product Research, 26(5), 405-415. doi:10.1080/14786419.2010.490216

Salgueiro, A. C. F., Folmer, V., da Rosa, H. S., Costa, M. T., Boligon, A. A., Paula, F. R., ... Puntel, G. O. (2016). In vitro and in silico antioxidant and toxicological activities of Achyrocline satureioides. Journal of Ethnopharmacology, 194, 6-14. doi:10.1016/j.jep.2016.08.048

Santos, A. L., Ripoll, D., Nardi, N., \& Bassani, V. L. (1999). Immunomodulatory effect of Achyrocline satureioides (LAM.) D.C. aqueous extracts. Phytotherapy Research, 13(1), 65-66. doi:10.1002/(SICI)1099-1573(199902)13:1<65::AID-PTR371>3.0.CO;2-Z

Siqueira, I. R., Simões, C. M. O., \& Bassani, V. L. (2020). Achyrocline satureioides (Lam.) D.C. as a potential approach for management of viral respiratory infections. Phytotherapy Research. doi:10.1002/ptr.6807

Sousa, F. M. S. de, Araujo, J. R. da S., Couto, L. M. F. C. B., Sousa, R. M. S., Oliveira, M. das D. A., Costa Júnior, J. S. da, ... Almeida, P. M. de. (2020). Cytogenotoxic potential of Terminalia actinophylla (Mart.) bark in Allium cepa L. Research, Society and Development, 9(9), e353997322. doi:10.33448/rsdv9i9.7322 
Research, Society and Development, v. 10, n. 1, e37610111902, 2021 (CC BY 4.0) | ISSN 2525-3409 | DOI: http://dx.doi.org/10.33448/rsd-v10i1.11902

Valera, Marcia C, Oliveira, S. A., Maekawa, L. E., Cardoso, F. G., Chung, A., Silva, S. F., \& Carvalho, C. A. (2016). Action of Chlorhexidine, Zingiber officinale, and Calcium Hydroxide on Candida albicans, Enterococcus faecalis, Escherichia coli, and Endotoxin in the Root Canals. The journal of contemporary dental practice, 17(2), 114-118. doi:10.5005/jp-journals-10024-1812

Valera, Marcia Carneiro, Cardoso, F. G. da R., Maekawa, L. E., Camargo, C. H. R., de Oliveira, L. D., \& Carvalho, C. A. T. (2015). In vitro antimicrobial and anti-endotoxin action of Zingiber Officinale as auxiliary chemical and medicament combined to calcium hydroxide and chlorhexidine. Acta odontologica Scandinavica, 73(7), 556-561. doi:10.3109/00016357.2014.949846

Viegas, D. de J., Amêndola, I., Botrel, T. M., De Oliveira, F. E., Figueira, L. W., Sper, F. L., ... De Oliveira, L. D. (2020). Schinus terebinthifolius (Brazilian Peppertree) extract used as antifungal to control Candida spp. in planktonic cultures and biofilms. Brazilian dental science, 23(4), 7p. doi: $10.14295 /$ bds.2020.v23i4.2077

Zanon, S. M., Ceriatti, F. S., Rovera, M., Sabini, L. J., \& Ramos, B. A. (1999). Search for antiviral activity of certain medicinal plants from Córdoba, Argentina. Revista latinoamericana de microbiologia, 41(2), 59-62. 